\title{
PENGARUH KOMPETENSI TERHADAP KINERJA PEGAWAI PADABIDANG KEPEMUDAAN DINAS PEMUDA DAN OLAHRAGA KOTA BANDUNG
}

\author{
Oleh \\ Heri $^{1}$, Fitri Andayani ${ }^{2)}$ \\ 1),2)Program Studi Ilmu Administrasi Negara \\ Fakultas IImu Sosial dan IImu Politik Universitas Al-Ghifari Bandung \\ Email: 1)achief1984@gmail.com, 2)fitriandayani495@gmail.com
}

\begin{abstract}
ABSTRAK. Penelitian ini berdasarkan masalah pokok yakni kinerja pegawai Dinas Pemuda dan Olahraga Kota Bandung yang rendah. Hal tersebut diduga karena belum dijalankannya indikator-indikator kompetensi pegawai secara menyeluruh pada Dinas Pemuda dan Olahraga (Dispora) Kota Bandung. Metodeyang digunakan dalam penelitian ini yaitu metode kuantitatif yang menitikberatkan pada pengolahan data menggunakan data statistik variabel kompetensi $(X)$ sebagai variabel bebas yang terdiri dari dimensi keterampilan, kemampuan dan etos kerja (Schumacher dalam Sinamo) dan variabel kinerja pegawai ( $Y$ ) sebagaivariabel terikat, terdiri dari dimensi kualitas kerja, ketepatan, Inisiatif, kemampuan dan komunikasi. Anggota populasi yang kemudian dijadikan sampel dengan teknik simple random sampling dalam penelitian ini berjumlah 35 orang dari 103 orang populasi penelitian. Hasil penelitian menunjukkan bahwa pengaruh kompetensi $(X)$ terhadap kinerja pegawai $(Y)$ sebesar $87,4 \%$. Pengaruh variabel lain $(\varepsilon)$ terhadap kinerja pegawai $(Y)$ sebesar $12,6 \%$ yang tidak diteliti dalam penelitian ini. Peneliti memberikan saran agar faktor-faktor yang mendukung semakin baiknya pengaruh kompetensi terhadap kinerja pegawai mendapat perhatian serius. Selain itu, disarankan untuk selalu memberikan pelatihan- pelatihan atau pendidikan lebih lanjut kepada pegawai agar kompetensi yang dimilki para pegawai pun meningkat guna tercapainya tujuan lembaga yang lebihmaksimal.
\end{abstract}

Kata Kunci: Kompetensi, Kinerja Pegawai, Dinas Pemuda dan Olahraga Kota Bandung

ABSTRACT. This research is based on the main problem, namely the low performance of the employees of the Bandung City Youth and Sports Service. This is allegedly due to the absence of comprehensive employee competency indicators at the Bandung City Youth and Sports Service (Dispora). The method used in this study is a quantitative method that focuses on data processing using statistical data on competency variables $(X)$ as independent variables consisting of the dimensions of skills, abilities and work ethic (Schumacher in Sinamo) and employee performance variables $(Y)$ as the dependent variable. , consisting of the dimensions of work quality, accuracy, initiative, ability and communication. Population members who were then sampled using simple random sampling technique in this study amounted to 35 people from 103 people in the study population. The results showed that the influence of competence $(X)$ on employeeperformance $(Y)$ was $87.4 \%$. The influence of other variables $(\varepsilon)$ on employee performance $(Y)$ is $12.6 \%$ which is not examined in this study. Researchers provide suggestions that the factors that support the better influence of competence on employee performance get serious attention. In addition, it is advisable to always provide further training or education to employees so that the competencies possessed by employees can increase in order to achieve maximum institutional goals.

Keyword: Competence, Employee Performance, Bandung City Youth and Sports Service 


\section{PENDAHULUAN}

Dinas Pemuda dan Olahraga Kota Bandung dibentuk berdasarkan Peraturan Daerah Nomor 13 Tahun 2009 pasal 17C yang mempunyai tugas melaksanakan sebagian urusan Pemerintah Daerah di Bidang Pemuda dan Olahraga berdasarkan asas otonomi dan pembantuan. Mengacu pada Peraturan Presiden Nomor 29 Tahun 2014 tentang Akuntabilitas Kinerja Intansi Pemerintah, Dinas Pemuda dan Olahraga Kota Bandung sebagai instansi pemerintah dan unsur penyelenggara negara diwajibkan menetapkan target kinerja dan melakukan pengukuran kinerja yang telah dicapai serta menyampaikan laporan Kinerja Instansi Pemerintah (LKIP). Berdasarkan Peraturan Daerah Nomor 13 Tahun 2009 Pasal 17C, untuk melaksanakan tugasnya tersebut Dinas Pemuda dan

Olahraga Kota Bandung mempunyaifungsi:

1. Perumusan kebijakan teknis di bidang pemuda dan olahraga;

2. Penyelenggaraan sebagian urusan pemerintah daerah dan pelayanan umum di bidang pemuda dan olahraga;

3. Pembinaan dan pelaksanaan tugas bidang pemuda dan olahraga yang meliputi kepemudaan, keolahragaan serta sarana dan prasarana;

Pelaksanaan teknis administratif Dinas; dan Pelaksanaan tugas lain yang diberikan Walikota sesuai dengan tugas dan fungsinya. Dinas Pemuda dan Olahraga Kota Bandung dalam melaksanakan tugas dan fungsinya, dibentuk susunan organisasi Dinas Pemuda dan Olahraga Kota Bandung berdasarkan Peraturan Gubernur Nomor 30 Tahun 2009 tentang susunan organisasi, kedudukan, dan tugas pokok yang terdiri dari Kepala Dinas dan Sekretaris Dinas. Untuk menjalankan semua kegiatan yang telah ditentukan dalam peraturan dalam hal ini Kepala Dinas dibantu oleh beberapa bidang.

Kemajuan suatu bangsa salah satunya ditentukan oleh kemampuan aparatur birokrasi dalam menjalankan tugas dan fungsinya, yaitu sebagai pelayan publik kepada masyarakat secara profesional dan akuntabel. Apabila publik dapat dilayani dengan baik oleh aparatur birokrasi, maka dengan sendirinya aparatur birokrasi mampu menempatkan posisi dan kedudukannya, yaitu sebagai civil servant atau public service.

Kondisi ini akan berdampak pada kinerja dari aparatur birokrasi sesuai dengan harapan masyarakat, yang pada akhirnya akan timbul trust kepada aparatur birokrasi tersebut. Hal inilah yang akan menjadikan suatu negara menjadi negara yang maju dalam hal pelayanan kepada warganya dan terwujudnya birokrasi yang bersih, akuntabel, dan trasparan.

Budaya aparatur negara menjadi penting apabila birokrasi mampu mendukung terwujudnya kesejahteraan umum melalui fungsi dan perannya sebagai pelayan masyarakat. Tugas inilah yang menjadi tanggung jawab aparatur birokrasi, selain itu pula keberadaan aparatur sipil Negara 
(ASN) menjadi kata kunci dari keberlangsungan suatu negara terutama dalam pelayanan publik. Peran besar yang diemban oleh ASN inilah yang menjadikan ASN dibutuhkan oleh masyarakat dan memiliki kedudukan strategis dalam kehidupan bernegara dan bermasyarakat. ASN juga menjadi simbol berlangsungnya sistem dan identitas dari kepemerintahan apakah berjalan dengan baik dan bersih ataukah sebaliknya, itu semua tidak lepas dari peran dan fungsi ASN.

Sesuai dengan harapan tersebut, Aparatur Sipil Negara harus bekerja sesuai dengankompetensinya masing-masing agar kinerja Aparatur Sipil Negara bisa optimal. Optimalisasi kinerja pegawai di lingkungan Dinas Pemuda dan Olahraga Kota Bandung begitupenting dalam membentuk danmengembangkan kemampuan aparat pemerintah yang handal dan memiliki kapabilitas yang tinggi dalam menjalankan tugas sebagai pengemban amanat publik. Selain itu, untuk mengantisipasi tuntutan pelayanan publik yang semakin tinggi juga pentingnya optimalisasi kemampuan individu pegawai dalam suatu karir, sebab pentingnya implementasi kompetensi seorang pegawai diduga berpengaruh terhadap kinerja pegawai yang ada di lingkungan Dinas Pemuda dan Olahraga Kota Bandung masihrendah dan belum optimal.

$$
\text { Adapun jumlah pegawai }
$$
berdasarkan tingkat pendidikanya yakni sebagai berikut:
Tabel 1

Jumlah Pegawai BerdasarkanTingkat Pendidikan

\begin{tabular}{ccc}
\hline No & $\begin{array}{c}\text { Tingkat } \\
\text { Pendidikan }\end{array}$ & Jumlah (orang) \\
\hline 1. & S3 & 1 \\
2. & S2 & 10 \\
3. & S1 & 43 \\
4. & D3 & 5 \\
5. & SMA & 36 \\
6. & SMP & 4 \\
7. & SD & 4 \\
\hline & Jumlah
\end{tabular}

Sumber: Dispora Kota Bandung,2019

Berdasarkan hasil penjajakan awal, bahwa kinerja pegawai yang ada pada Bidang Kepemudaan Dinas Pemuda dan Olahraga Kota Bandung masih rendah, di antaranya terlihat dari:

1. Aspekketerampilan: Keterampilan yang dimiliki para pegawai masih belum optimal, dan bisa dikatakan masih minimnya penguasaan teknologi, khususnya berkaitan dengan pengetikan komputer sehingga kinerja pegawai menjadi lamban.

2. Aspek kemampuan: kemampuan yang dimiliki oleh pegawai belum maksimal. Hal ini dapat dilihatdari proses pengetikan sering terjadi kesalahan, sehingga menghamburkan perlengkapan berbentukkertas hasil print yang tidak terpakai. 
3. Aspek etos kerja: etos kerja pegawai yang masih rendah. Hal ini terlihat dari masih ada pegawai yang kurang memahami tugas dan fungsinya sebagai pegawai serta kurang meratanya pembagian tugas kerja, sehingga ada yang mendapatkan pekerjaan yang banyak dan ada yang mendapatkan pekerjaan

4. sedikit dari pimpinan karena dilihat dari kemampuan kerjapegawainya.

5. Bertitik tolak dari uraian tersebut, maka peneliti tertarik untuk melakukan penelitian lebih lanjut dengan judul "Pengaruh Kompetensi terhadap Kinerja Pegawai pada Bidang Kepemudaan Dinas Pemuda dan Olahraga Kota Bandung".

Berdasarkan latar belakang di atas, maka peneliti merumuskan masalah sebagai berikut: Berapa besar pengaruh kompetensi terhadap kinerja pegawai pada DinasPemuda dan Olahraga Kota Bandung?. Maksud dari penelitian iniadalah untuk mendapatkan data daninformasi tentang berapa besar pengaruh kompetensi terhadap kinerja pegawai pada Dinas Pemudadan Olahraga Kota Bandung. Tujuan penulis melakukan penelitian ini adalah untuk mengetahui berapa besar pengaruh kompetensi terhadap kinerja pegawai pada Dinas Pemuda dan Olahraga Kota Bandung.

\section{TINJAUAN PUSTAKA}

Kompetensi atau kemampuan merupakan salah satu unsur yang penting dalam menujang kinerja pegawai dalam sebuah organisasi. Pegawai yang memiliki kemampuan yang baik dapat menunjang tercapainya visi dan misi organisasi untuk segera maju danberkembang pesat guna menghadapi kompetisi global yang semakin maju.

Spencer dalam Moeheriono (2014: 5) mendefinisikan kompetensi "sebagai karakteristik yang mendasari seseorang yang berkaitan dengan efektivitas kinerja individu dalam pekerjaannya atau karakteristik dasar individu yang memiliki hubungan kausal atau sebagai sebab akibat dengan kriteriayang dijadikan acuan, efektif atau berkinerja prima atau superior di tempat kerja atau pada situasi tertentu".

Berdasarkan dari arti definisi kompetensi ini, maka banyak mengandung beberapa makna yang terkandung di dalamnya sebagai berikut:

1. Karakteristik dasar (underlying characteristic) kompetensi

adalah bagian dari kepribadian yang mendalam dan melekat pada seseorang serta mempunyai perilaku yang dapat diprediksi pada berbagai keadaan tugas pekerjaan.

2. Hubungan kausal (causally related) berati kompetensi yang dapat menyebabkan ataudigunakan untuk memprediksi kinerja seseorang artinya jika mempunyai kompetensi yang tinggi maka akan mempunyai kinerja yang tinggi pula 
(sebagaiakibat).

3. Kriteria (criterian referenced) yang dijadikan sebagai acuan, bahwa kompetensi secara nyata akan memprediksi seseorang dapat bekerja dengan baik, harus terukur dan spesifik atau terstandar.

Selain definisi tersebut, Moeheriono (2014: 5) menyatakan bahwa kompetensi merupakan "sebuah karakteristik dasar seseorang yang mengindikasikan cara berfikir, bersikap, dan bertindakserta menarik kesimpulan yang dapat dilakukan dan dipertahankan oleh seseorang pada waktu periode tertentu".

Karakteristik dasar tersebut menampakkan tujuan penentuan tingkat kompetensi atau standar kompetensi yang dapat mengetahui tingkat kinerja yang diharapkan dan mengategorikan tingkat tinggi atau di bawah rata-rata. Oleh karena itu, penentuan ambang kompetensi tersebut sangat dibutuhkan dan tentunya penting sekali, karena akan dapat dijadikan sebagai dasar pertimbangan bagi proses rekrutmen, seleksi, perencanaan, evaluasi kinerja dan pengembangan sumber daya manusia lainnya.

Kompetensi terletak pada setiap bagian dalam setiap manusia dan selamanya ada padakepribadian seseorang yang dapat memprediksikan tingkah laku dan performansi secara luas pada semua situasi dan tugas pekerjaan atau job staks. Sedangkan menurut Amstrong dalam Moeheriono (2014: 6) kompetensi adalah "dimensi tindakan dari tugas, dimana tindakan tersebut dipakai oleh karyawan untuk menyelesaikan tugas pekerjaan mereka dengan memuaskan dan apa yang diberikan karyawan dalam bentuk yang berbeda-beda dan tingkatan kinerjanya". Akan tetapi Mc Clelland dalam Moeheriono (2014: 6) mengatakan bahwa kompetensi adalah "sebagai karakteristik dasar personal yang menjadi faktor penentu sukses tidaknya seseorang dalam mengerjakan suatu pekerjaanatau pada situasi tertentu".

Secara umum bahwa kompetensi sebagai karakteristik dasar yang terdiri dari keterampilan (skills), pengetahuan (knowledge) serta atribut personal (personal atributs) lainnya. Yang mampu membedakan seseorang mampu melakukan dan tidak melakukan saja. Artinya, inti utama dari sistem atau model kompetensi ini sebenarnya adalah sebagai alat penentu untuk memprediksi keberhasilan kerja seseorang pada posisi tertentu.

Menurut Mangkunegara (2005 : 67) "Kinerja adalah hasil kerjasecara kualitas dan kuantitas yang dicapai oleh seorang pegawai dalammelaksanakan tugasnya sesuaidengan tanggung jawab yang diberikan kepadanya". Kemudian menurut Sulistiyani (2003: 223) "kinerja merupakan kombinasi dari kemampuan, usaha dan kesempatan yang dapat dinilai dari hasil kerjanya". Sedangkan Hasibuan (2007: 34) mengemukakan bahwa "kinerja (prestasi kerja) adalah suatu hasil kerja yang dicapai seseorang dalam melaksanakan tugas-tugas yang dibebankan kepadanya yangdidasarkan atas kecakapan, 
pengalaman, kesungguhan danwaktu".

Menurut Widodo (2010: 78) "kinerja adalah melakukan suatu kegiatan dan menyempurnakannya sesuai dengan tanggung jawab dengan hasil seperti yang diharapkan".

Sedangkan

menurut

Moeheriono (2014: 95) "kinerja atau performance merupakan gambaran mengenai tingkat pencapaian pelaksanaan suatu program kegiatan atau kebijakan dalam mewujudkansasaran, tujuan, visi dan misi organisasi yang dituangkan melalui perencanaan strategis suatu organisasi".

Beberapa definisi kinerja yang telah dikemukakan tersebut, dapat disimpulkan bahwa kinerja merupakan hasil kerja yang dapat dicapai seseorang, kelompok, atau organisasi sesuai dengan kewenangan masing-masing dalam rangka mencapai tujuan organisasi yang telah ditentukan sebelumnya pada periode waktu tertentu. Menurut Kamus Besar Administrasi Publik, pengukuran kinerja adalah “...an evalution of an employee's progress or lack of progress measured in terms of job effectiveness..." (Chandler \& Plano, 2008). Artinya dalam batasan penilaian kerja atau evaluasi kinerja menekankan pada evaluasi kemajuan dan kegagalan dari seorang pegawai dan penilaian kerja yang efektif tidak hanya sekedar melakukan penilaian untuk mendapatkan gambaran mengenai keberhasilan atau kegagalan kinerja dalam pelaksanaan pekerjaan/tugas- tugas dalam jabatannya, melainkan harus diteruskan dengan melakukan diagnosis dan analis penyebab- penyebab yang diperolehnya kinerja tertentu, serta mencari strategi perbaikan yang sesuai dengan faktor penyebab yang dikemukakan.

Dimensi atau indikator kinerja merupakan aspek-aspek yangmenjadi ukuran dalam menilai kinerja. Ukuran-ukuran tersebut dijadikan tolak ukur dalam menilai kinerja. Dimensi atupun ukurankinerja sangat diperlukan karena akan bermanfaat baik bagi banyak pihak. Adapun literatur mengenai dimensi atau indikator yang menjadi ukuran kinerja adalah:

Miner (dalam Sudarmanto, 2009: 11) mengemukakan 4 dimensi yang dapat dijadikan sebagai tolak ukur dalam menilai kinerja, yaitu:

Kualitas, yaitu tingkat kesalahan, kerusakan dan kecermatan,

1. Kuantitas, yaitu jumlah pekerjaan yang dihasilkan.

2. Penggunaan waktu dalam kerja,yaitu tingkat ketidakhadiran, keterlambatan, waktu kerja efektif/jam kerja hilang.

3. Kerja sama dengan orang lain dalam bekerja.

Dari empat dimensi kinerja di atas, dua hal terkait dengan aspek keluaran atau hasil pekerjaan, yaitu: kualitas hasil, kuantitas keluaran; dan dua hal terkait aspek perilaku individu, yaitu: penggunaan waktu dalam kerja (tingkat kepatuhanterhadap jam kerja, disiplin) dan kerja sama. Dari empat dimensi tersebut cenderung mengukur kinerja pada level individu. Secara teoritik efektivitas dari penilaian kinerja dapat 
dipengaruhi oleh beberapa faktor berdasarkan model penilaian. Moeheriono (2014:96) mengemukakan bahwa kinerja dipengaruhi oleh beberapa faktor, yaitu:

1. Harapan mengenaiimbalan Dorongan,

2. Kemampuan,

3. Kebutuhan dan sifat,

4. Persepsi terhadap tugas,

5. Imbalan internal daneksternal, serta

6. Persepsi terhadap tingkat imbalan dan kepuasan kerja.

Faktor kemampuan menjadi salah satu faktor utama dari kinerja pegawai. Karena kemampuan mencangkup kemampuan teknis, kemampuan manajerial, kemampuan perilaku dan kemampuan konseptual (Hersey \&Blanchard, 1992: 5). Sedangkan

menurut Mahmudi (2010: 10) faktor yang mempengaruhi kinerja adalah:

a. Faktor personal/individual, meliputi pengetahuan, keterampilan (skill), kemampuan, kepercayaan diri, motivasi dan komitmenyang dimiliki oleh seorang individu.

b. Faktor kepemimpinan, meliputi kualitas dalammemberikan dorongan, semangat, arahan dn dukungan yang diberikanmanajer dan team leader.

c. Faktor tim, meliputi kualitas dukungan dan semnagat yang diberikan oleh rekan dalam satu tim, kepercayaan terhadap sesama anggota tim, kekompakan dankeeratan anggota tim.

d. Faktor sistem, meliputi seistem kerja, fasilitas kerja dan infrastruktur yang diberikan oleh organisasi, proses organisasi dan kultur kinerja dalam organisasi.

e. Faktorkonstektual (situasional), meliputi tekanan dan perubahan lingkungan internal dan eksternal.

Terkait dengan konsep kinerja, Rummler \& Brache (dalam Sudarmanto,2009:7) mengemukakan ada 3 (tiga) level kinerja, yaitu:

1. Kinerja organisasi, merupakan pencapaian hasil (output come) pada level atauunit analisis organisasi. Kinerja pada organisasi ini terkait dengan tujuan organisasi dan manajemen organisasi.

2. Kinerja proses, merupakan kinerja pada proses tahapan dalam menghasilkan produk atau pelayanan. Kinerja pada level proses ini dipengaruhi oleh tujuan proses, rancangan proses dan manajemen proses.

3. Kinerja individu/pekerjaan, merupakan pencapaian atau efektivitas pada tingkat pegawai atau pekerjaan. Kinerja pada level ini dipengaruhi oleh tujuan pekerjaan, rancangan pekerjaan, dan manajemen pekerjaan serta karakteristik individu.

Sedangkan Grote (1996: 11) menyatakan bahwa dalam pengukuran atau penilaian kinerja ada tiga pendekatan, yaitu:

1. Penilaian atau pengukurankinerja berbasis pelaku.

2. Penilaian atau pengukurankinerja berbasis perilaku.

3. Penilaian atau pengukurankinerja bebasis hasil. 
Dari berbagai pendapat para ahli tersebut, standar pengukuran kinerja dapat dilakukan dengan mengukur 4 hal, yaitu:

1. Pengukuran kinerja dikaitkan dengan analisispekerjaan/uraian pekerjan.

2. Pengukuran kinerja dilakukan dengan mengukursifat/karakter pribadi (traist).

3. Pengukuran kinerja dapat dilakukan dengan mengukur hasil dari pekerjaan yangdicapai.

4. Pengukur kinerja dilakukan dengan mengukur perilaku atau tindakan dalam mencapai hasil.

Pencapaian tujuan negara untuk menyejahterakan rakyat harus ditopang oleh kompetensi atau kemampuan dan kinerja pegawai publik yang optimal, sehingga rakyattidak merasa dikecewakan dengan beberapa pengorbanan yang telah diberikan oleh rakyat untuk negaranya. Keberhasilan suatuorganisasi bukan hanya ditunjang oleh motivasi saja akan tetapi juga oleh kompetensi yang dimiliki oleh para pegawainnya guna mendorong peningkatan kinerja pegawai yang lebih optimal, sehingga dapat dipastikan meningkat atau tidaknya kinerja pegawai tergantung pada kompetensi atau kemampuan yang dimiliki oleh para pegawain pada organisasi tersebut. Spencer dalam Muheriono (2014: 5) mengemukakan bahwa kompetensi dapat didefinisikan "sebagai karakteristik yang mendasari seseorang yang berkaitan dengan efektivitas kinerja individu dalam pekerjaannya atau karakteristik dasar individu yang memiliki hubungan kausal atau sebagai sebab akibat dengan kriteria yang dijadikan acuan, efektif atau berkinerja prima atau superior di tempat kerja atau pada situasi tertentu". Hubungan antara pegawai dengan organisasi merupakan suatu yang dinamis yang cenderung berubah-ubah karena berbagai pihak yang saling menyesuaikan diri dengan harapan-harapan dengan kontribusi yang ingin diberikan kepada pihak lain dalam sebuah organisasi.

Komponen kemampuan menurut Schumacher dalam Sinamo (2004: 23), ada tiga komponen penting yang tampak dalam kemampuan diri manusia, yaitu:

1. Keterampilan, yang dimiliki oleh karyawan dimiliki didasarkan atas pengalaman yang dilakukannya selama bekerja. Keterampilan dapat meningkat apabila seorang karyawan memiliki masa kerja lebih lamadibandingkan dengan karyawan yang memilikimasa kerja lebih sedikit.

2. Kemampuan, yang dimiliki oleh pegawai didasarkan atas bakat yang dibawanya semenjak kecil atau yang diperolehnya pada masa mengikuti pendidikan, semakin baik pendidikan seorang pegawai maka semakin tinggi pula kemampuan yangdierolehnya..

Etos Kerja, dihubungkan dengan sikap dan motivasipegawai dalambekerja. Prinsip yang tidak kenal lelah dalam bekerja sebagai dasar yang tinggi yang dimiliki oleh seorang karyawan. Komponen 
kemampuan dari Shumacher dalam Sinamo tersebut di atas menjadi salah satu alat ukur untuk variabel bebas yaitu kompetensi/kemampuan pegawai. Kemampuan atau kompetensi dalam organisasi merupakan bagian dari pengendalian yang diatur secara resmi, yang dimana suatu organisasi akan mengeluarkan berbagai peraturan atau kebijakan yang terkait dengan kepentingan organisasi dan pegawai di dalamnya. Kedua variabel yang dijabarkan melalui teori-teori dasar utama dan pendukung dalam penelitian ini dimaksdkan agar mampu membangkitkan variabel kinerja pegawai. Dengan harapan semakin efektif variabel kompetensi pegawai maka diharapkan akan dapat meningkat pula kinerja pegawainnya.

Kinerja dalam organisasi merupakan jawaban dari berhasil atau tidaknya tujuan organisasi yang telah ditetapkan. Dimensi atau indikator kinerja merupakan aspek- aspek yang menjadi ukuran dalam menilai kinerja. Ukuranukuran tersebut dijadikan tolak ukur dalam menilai kinerja. Dimensi atupun ukuran kinerja sangat dikperlukan karena akan bermanfaat baik bagi banyak pihak. Adapun literatur mengenai dimensi atau indikator yang menjadi ukuran kinerja adalah sebagai berikut:

Widodo (2010: 78) menjelaskan bahwa "kinerja adalah melakukan suatu kegiatan dan menyempurnakannya sesuai dengan tanggung jawab dengan hasil seperti yang diharapkan". Sedangkan
Michell dalam buku Sedarmayanti (2009: 11) mengemukakan 5 dimensi yang dapat dijadikan sebagai tolak ukur dalam menilai kinerja, yaitu:

1. Kualitas, yaitu mutu yang dihasilkan berhubungan dengan baik tidaknya hasil pekerjaan yang telah dicapai. Kualitas tersendiri dan segalasesuatu yang bebas dan kekurangan atau kerusakan.

Ketepatan, yaitu berkaitan dengan sesuai atau tidaknya waktu penyelesaian pekerjaan dengan target waktu yang telah ditentukan dan memanfaatkan waktu yang se-efisien mungkin.

2. Inisiatif, yaitu perubahan wujud pengambilan keputusan yang dimiliki pegawai dalam menyelesaikan pekerjaannya. Sebagai seorang pemimpin harus memberikan dorongan dan kesempatan kepada bawahannya untuk berinisiatif dengan memberikan kesempatan kepada bawahan agar aktif memikirkan dan menyelesaikan sendiri tugas- tugasnya dan tidak terlalu bergantung padapimpinannya.

Kemampuan, yaitu kecakapan, sikap mental dan unsur-unsur fisik yang dimiliki pegawai dalam menyelesaikan pekerjaannya. Setiap pegawai harus mengetahui bidang pekerjaan yang ditekuninya. Serta mengetahui arah yang diambil organisasi, sehingga jika telah menjadi keputusan mereka tidak ragu-ragu lagiuntuk melaksanakannya dalam mencapai tujuan organisasi. 
3. Komunikasi, yaitu menyangkut kelancaranberinteraksi dalam organisasi baik secara vertikal maupun horizontal.

Seorang pemimpin dalam mengambil keputusan terlebih dahulu memberikan kesempatan kepada bawahannya untuk mengemukakan saran dan pendapatnya serta mengajak para bawahannya untuk ikut berpartisipasi dalam memecahkan masalah yang dihadapi, keputusan terakhir tetap berada ditangan pemimpin yang dimana akan menimbulkan kerja sama yang lebih baik lagi dan hubungan yang semakin harmonis juga menimbulkan perasaan senasib sepenanggungan.

Dimensi kinerja yang dikemukakan tersebut menjadi alat ukur untuk variabel terikat yaitu kinerja pegawai. Penilaian prestasi kerja merupakan hal yang paling penting karena merupakan suatu proses organisasi dalam menilai kinerja pegawainya, sekaligus menjadi landasan sejauh mana manajemen sumber daya manusia menjalankan kegiatan tersebut. Keterkaitan pengaruh kompetensi terhadap kinerja pegawai, dengan melihat antara kompetensi pegawai dan kinerja nampaknya merupakan suatu hal yang penting dalam rangka peningkatan kinerja di dalam organisasi, ketika unit kerja meningkat disebabkan oleh para pegawai atau karyawan telah memiliki kompetensi atau kemampuan kerja yang optimal, karena sense of belong (rasamemiliki) para karyawan yang secara emosional telah terikat kuat terhadap organiasasi tersebut.
Hubungan antara kompetensi dengan kinerja sangat erat sekali, hal ini tampak pada hubungan dari keduanya, yaitu hubungan sebab akibat (causally related). Oleh karena itu, menurut Spencer dalam Moeheriono (2014: 10), hubungan antara kompetensi pegawai dengan kinerja pegawai adalah sangat erat dan penting sekali, relevansinya ada dan kuat akurat, bahkan pegawai apabila inginmeningkatkan kinerja seharusanya mempunyai kompetensi yang sesuai dengan pekerjaannya. Berdasarkan uraian kerangka pemikiran di atas, maka disusun paradigma pemikiran sebagai berikut:

Gambar 1. Kerangka Pemikiran

\begin{tabular}{|l|l|l|}
\hline $\begin{array}{c}\text { Kompetensi } \\
\text { (kemampuan) } \\
\text { pegawai } \\
\text { Schumacher } \\
\text { dalam Sinamo } \\
(2004: 6)\end{array}$ & \begin{tabular}{|l|l|} 
Dimensi/aspek \\
Kinerja \\
Michell dalam \\
Sedarmayanti \\
$(2009: 11)$
\end{tabular} \\
\hline $\begin{array}{l}\text { Komponen- } \\
\text { komponen: } \\
\text { Keterampilan } \\
\text { Kemampuan } \\
\text { Etos kerja }\end{array}$ & $\begin{array}{l}\text { Dimensi- } \\
\text { dimensi: } \\
\text { Kualitas kerja } \\
\text { Ketetapan } \\
\text { Inisiatif } \\
\text { Kemampuan } \\
\text { Komunikasi }\end{array}$ \\
\hline
\end{tabular}

\section{HASIL DAN PEMBAHASAN}

Hasil penelitian menunjukkan bahwa kompetensi berpengaruh secara simultan terhadap kinerja pegawai pada Bidang Kepemudaan Dinas Pemuda dan Olahraga Kota Bandung sebesar 87,4\%. Hasil uji signifikansi menunjukkan bahwa kompetensi berpengaruh secara signifikan terhadap kinerja pegawai pada Dinas Pemuda dan Olahraga Kota Bandung.

Artinya apabila kompetensi yang dimiliki pegawai pada Bidang Kepemudaan 
Dinas Pemuda dan Olahraga Kota Bandung sudah cukup baik, maka kinerja pegawai pun akan semakin optimal. Kompetensi memiliki pengaruh yang cukup besar terhadap kinerja pegawai, artinya pegawai yang memiliki kompetensi atau kemampuan yang baik dalam mengerjakan seluruh tugas pekerjaan yang diberikan oleh pimpinan otomatis akan memberikan kemudahan bagi semua pihak untuk menghasilkan kinerja yang senakin optimal apabila ditunjang dengan berbagai fasilitas serta sarana dan prasaran yang memadai dan dimanfaatkan dengan baik guna tercapainya tujuan organisasi yang lebih optimal. Masing-masing pegawai harus mampu mencapai tujuan organisasi, agar semua tugas, kegiatan, terintegrasi pada sasaran yang diinginkan.

Hasil wawancara dengan Kepala Bagian Kepegawaian Dinas Pemuda dan Olahraga Kota Bandung didapatkan informasi bahwa kompetensi yang dimiliki oleh para pegawai yang ada di lingkungan DISPORA Kota Bandung belum optimal dan masih harus ditingkatkan, apalagi dalam halkemampuan/keterampilan masih perlu ditingkatkan untuk lebih memaksimalkan potensi yang dimiliki, selain itu juga pegawai harus memiliki pendidikan yang memadai supaya dalam menjalankan pekerjaanna tidak terlalu banyak mendapatkan hambatan, oleh karena itu indikator tersebut perlu untukdiperhatikan dengan serius bahkan ditingkatkan kembali. Selain itu juga pendidikan yang sesuai dengan pekerjaan juga kompetensi yang sesuai dengan pekerjaan adalah bagian penting untuk memperoleh hasil kinerja yang baik.

Selanjutnya dari segi ketepatan waktu dalam menyelesaikan tugas para pegawai masih harus ditingkatkan karena berpengaruh terhadap kualitas pekerjan yang dihasilkan serta dari segi penyampaian informasi daripimpinan masih belum optimal dikarenakan kadang pimpinan hanya menyampaikan informasikebeberapa bagian saja belum begitu menyeluruh jadi seringkali terjadi miss komunikasi baik antar sesama pegawai maupun dengan pimpinan.

Berdasarkan uraian tersebut, kompetensi merupakan faktor yang sangat penting dalam menunjang kinerja pegawai. Karena tanpa adanya kompetensi maka kinerja pegawai tidak akan berjalan dengan efektif sesuai dengan yang diharapkan, kompetensi yang baik akan menghasilkan hasil positif yang sangat besar terhadap peningkatan kinerja pegawai sehingga terciptanya kualitas kerja yang maksimal. Tanpa kompetensi pegawai yang baik maka tujuan organisasi akan sulit untuk dicapai. Pencapaian kinerja pegawai pada Bidang Kepemudaan Dinas Pemuda dan Olahraga Kota Bandung terhadap pelaksanaan program kerja tahun 2018, dapat dilihat dari pencapaian kinerja kebijaksanaan sebagai capaian menyeluruh terhadap program dan kegiatan yang dilaksanakan.

Berdasarkan hal tersebut dapat dianalisis bahwa organisasi dapat dipandang sebagai wadah atau tempat orang saling bekerja sama dalam 
melaksanakan kegiatan-kegiatan dalam rangka pencapaian tujuan yang telah ditetapkan sebelumnya. Organisasi juga dipandang sebagai saluran hierarki kedudukan atau jabatan yang ada menggambarkan secara jelas wewenang garis komando, dan garis tanggung jawab juga bisa disebut garis koordinasi.

Perkembangan lingkungan eksternal organisasi termasuk di dalamnya kemajuan teknologi, maka terjadi spesialisasi bidang pekerjaan dalam unit organisasi serta keahlian yang dimiliki individu. Untuk mencapai tujuan organisasi perlu adanya kompetensi karena kompetensi adalah salah satu prinsip dari organisasi atau dengan perkataan lain sebagai jalan untuk mencapai suatu kondisi yang diinginkan. Tujuan organisasi yangtelah ditetapkan adalah suatu kondisi yang telah disepakati oleh semua anggota organisasi. Jelaslah bahwa kompetensi merupakan faktor yang sangat penting yang harus dimiliki oleh semua pegawai dalam menunjang kinerja, dalam suatu organisasi yang baik dalam mekanisme kerja sangat tergantung kepada kompetensi atau kemampuan yang dimiliki para pegawainya guna mencapai tujuan orgasinasi yang telah disepakati sebelumnya.

\section{KESIMPULAN}

Berdasarkan hasil penelitian dan pembahasan, peneliti memberikan simpulan bahwa, kompetensi pegawai berpengaruh sangat tinggi dan signifikan terhadapkinerja pegawai pada Bidang Kepemudaan Dinas
Pemuda dan Olahraga Kota Bandung. Kompetensi diukur melalui indikator keterampilan, kemampuan dan etos kerja pada Bidang Kepemudaan Dinas Pemuda dan Olahraga Kota Bandung dengan besaran pengaruh sebesar $87.4 \%$ (delapan puluh tujuh koma lima persen). Hal ini membuktikan bahwa kompetensimempunyai pengaruh posistif terhadap kinerja pegawai. Sedangkan sisanya yakni sebesar $12.6 \%$ (dua belas koma lima persen)merupakan hal lain yang tidak diteliti yang berpengaruh terhadap peningkatan kinerja pegawai pada Bidang Kepemudaan Dinas Pemuda dan Olahraga Kota Bandung. Artinya bahwa kompetensi pegawai telah disaring/diseleksi sebagaimana mestinya dan berpengaruh signifikan terhadap kinerja pegawai pada Bidang Kepemudaan di Dinas Pemuda dan Olahraga Kota Bandung.

Adapun saran yang diberikan oleh peneliti bagi kemajuan dankebaikan Bidang Kepemudaan Dinas Pemuda dan Olahraga Kota Bandung sebagai berikut:

1. Kompetensi pegawai pada Bidang Kepemudaan Dinas Pemuda dan Olahraga Kota Bandung perlu memperhatikan indikator bahwa setiap pegawai harus memiliki keterampilan dan pendidikan yang memadai untuk menigkatkan kinerja juga ditunjang dengan fasilitas dan bergai sarana dan prasarana guna meningkatkan kinerja pegawai yang semakin maksimal, peneliti menyarankan untuk selalu memberikan pelatihan-pelatihan atau pun pendidikan lebih lanjut terkait 
dengan tugas dan beban yang diberikan kepada pegawai supaya kompetensi pegawai lebih meningkat.

2. Kinerja pegawai pada Dinas Pemuda dan Olahraga Kota Bandung disarankan untuk selalu ditingkatkan dalam beberapa indikator, yakni dalam hal pekerjaan yang diberikan dapat diselesaikan tepat waktu serta penyampaian informasi dari pimpinan harus diperbaiki dan lebih ditingkatkan lagi, dengan memperbaiki indikator tersebut diharapkan dapat lebih meningkatkan kinerja parapegawainya.

\section{DAFTAR PUSTAKA}

Chandler, Ralph C dan Plano, Jack C. 2008. The Public administration Dictonary. New York: Basil Blackwell

Hasibuan, Malayu S.P. 2007. Manajemen Sumber Daya Manusia. Jakarta: PT. Gunung Agung.

Hersey, P dan Knneth, H, Blanchard.1992. Manajemen dan PerilakuOrganisasi, Jakarta: Bumi Aksara.

Mahmudi. 2010. Manajemen KinerjaSektor Publik. Yogyakarta: UPP STIMYKPN.

Mangkunegara, A. A. Anwar Prabu, 2005. Manajemen Sumber Daya Manusia Perusahaan.Moheriono. 2014. PengukuranKinerja Berbasis Kompetensi. Surabaya: PT. Raja Grafindo Persada.

Sedarmayanti. 2009. Sumber Daya Manusia dan produktivitas Kerja. Bandung: Mandar Maju.

Sudarmanto. 2009. Kinerjadan Pengembangan KompetensiSDM. Yogyakarta : PustakaPelajar.

Sinamo, Jensen H, 2004. Etos Kerja Profesional Diera Digital Global, Edisi
III, Jakarta :Institut Dharna Mahardika.

Sulistiyani, Ambar teguh \& Rosidah. 2003. Manajemen Sumber Daya Manusia, Konsep, Teori dan Pengembangan dalam Konteks Organisasi Publik. Yogyakarta: Penerbit Graha IImu.

Widodo. 2010. Membangun Birokrasi Berbasis Kinerja. Malang: Bayumedia Publishing. 